\title{
Coronavirus: proteomics analysis of chicken kidney tissue infected with variant 2 (IS-1494)-like avian infectious bronchitis virus
}

\author{
Hamed Abdollahi ${ }^{1,3} \cdot$ Mostafa Rezaei-Tavirani $^{1} \cdot$ Arash Ghalyanchilangeroudi $^{2}\left({ }^{\circ} \cdot\right.$ Hossein Maghsoudloo $^{3}$. \\ Masood Hashemzadeh ${ }^{4} \cdot$ Hossein Hosseini ${ }^{5} \cdot$ Abbas Barin $^{2}$
}

Received: 29 February 2020 / Accepted: 3 August 2020 / Published online: 20 October 2020

(c) Springer-Verlag GmbH Austria, part of Springer Nature 2020

\begin{abstract}
Avian infectious bronchitis virus is one of the most important gammacoronaviruses, which causes a highly contagious disease. In this study, we investigated changes in the proteome of kidney tissue of specific-pathogen-free (SPF) chickens that were infected with an isolate of the nephrotropic variant 2 genotype (IS/1494/06) of avian coronavirus. Twenty 1-day-old SPF White Leghorn chickens were randomly divided into two groups, each comprising 10 chickens, which were kept in separate positive-pressure isolators. Chickens in group A served as a virus-free control group up to the end of the experiment, whereas chickens in group B were inoculated with $0.1 \mathrm{ml}$ of $10^{4.5} \mathrm{EID}_{50}$ of the IBV/chicken/Iran/UTIVO-C/2014 isolate of IBV, and kidney tissue samples were collected at 2 and 7 days post-inoculation (dpi) from both groups. Sequencing of five protein spots at $2 \mathrm{dpi}$ and 22 spots at $7 \mathrm{dpi}$ that showed differential expression by two-dimensional electrophoresis (2DE) along with fold change greater than 2 was done by MS-MALDI/TOF/TOF. Furthermore, the corresponding protein-protein interaction (PPI) networks at 2 and $7 \mathrm{dpi}$ were identified to develop a detailed understanding of the mechanism of molecular pathogenesis. Topological graph analysis of this undirected PPI network revealed the effect of 10 genes in the 2 dpi PPI network and nine genes in the 7 dpi PPI network during virus pathogenesis. Proteins that were found by 2DE analysis and MS/TOF-TOF mass spectrometry to be down- or upregulated were subjected to PPI network analysis to identify interactions with other cellular components. The results show that cellular metabolism was altered due to viral infection. Additionally, multifunctional heat shock proteins with a significant role in host cell survival may be employed circuitously by the virus to reach its target. The data from this study suggest that the process of pathogenesis that occurs during avian coronavirus infection involves the regulation of vital cellular processes and the gradual disruption of critical cellular functions.
\end{abstract}

Handling Editor: Yue Wang.

Electronic supplementary material The online version of this article (https://doi.org/10.1007/s00705-020-04845-7) contains supplementary material, which is available to authorized users.

Arash Ghalyanchilangeroudi

arashghalyanchi@gmail.com; ghalyana@ut.ac.ir

1 Proteomics Research Center, Faculty of Paramedical Sciences, Shahid Beheshti University of Medical Sciences, Tehran, Iran

2 Department of Microbiology and Immunology, Faculty of Veterinary Medicine, University of Tehran, Tehran, Iran

3 National Reference Laboratory, Diagnosis \& Applied Studies Center, Iran Veterinary Organization, Tehran, Iran

4 Iranian Veterinary Organization, Tehran, Iran

5 Department of Clinical Sciences, Faculty of Veterinary Medicine, Karaj Islamic Azad University, Alborz, Iran

\section{Introduction}

Avian infectious bronchitis virus (IBV) is the most important gammacoronavirus, which can cause a highly contagious disease of the upper respiratory tract, reproductive tract, and urinary system in chickens. IBV is an enveloped virus belonging to the order Nidovirales, family Coronaviridae, subfamily Coronavirinae, genus Gammacoronavirus, and species Avian coronavirus. IBV infection leads to high morbidity and variable mortality, depending on stress, age, virus strain, and host immunity [1].

Different genotypes of IBV have emerged due to the large RNA size of the genome and its unique mechanism of replication involving multiple nested sets of subgenomic mRNAs [2,3]. The high mutation and recombination rates of IBV and the absence of cross-protection in most cases have made controlling the disease problematic. Studies of the virus's replication strategy, affect on the transcriptional 
and translational patterns of infected host cells, and pathogenicity can be helpful in combating the virus and enhancing the immune system's defense mechanisms.

Analysis of such interactions between the host and invading viruses requires a broad spectrum of efficient methods to overcome the challenges arising during the study of the molecular pathogenesis of IBV. Proteomics technologies are used to reveal cellular changes at the protein level. Recently, wide usage of proteomic approaches has been applied to investigate virus-host interactions [4-9]. Some studies have investigated proteome changes in cells infected with different strains of IBV [10-12]. Up to now, published research has been carried out on IBV strains such as H120 and IBV $\mathrm{CK} / \mathrm{CH} / \mathrm{LDL} / 97 \mathrm{I}$, but no studies have investigated proteome changes following infection with a variant 2 genotype [10, 13]. The nephropathogenicity of the variant 2 genotype isolate IS/1494/06 has been demonstrated [14].

IS/1494/06 is one of the most prevalent IBV strains in poultry flocks in many countries, especially in the Middle East region, [14-16]. The purpose of this study was to acquire knowledge about the proteome of the kidney tissue of specific-pathogen-free (SPF) chickens infected with a local isolate of a nephrotropic variant 2 genotype (IS/1494/06). To obtain a snapshot of the situation in infected cells at a specific time point, we use a combination of two-dimensional gel electrophoresis (2DE) and MALDI/ TOF-TOF mass spectrometry. The aim was to find out how disease is initiated and to identify a protein-protein interaction network that might help to explain the complexities of IBV infection.

\section{Materials and methods}

\section{Ethics statement}

This study was carried out according to the ethical guidelines of the Iranian Ministry of Health.

\section{Experimental design}

Twenty 1-day-old SPF White Leghorn chickens were provided by Razi Vaccine and Serum Research Institute (Iran, Karaj). The chickens were divided randomly into two groups. Each group consisted of $10 \mathrm{SPF}$ chickens that were kept in a separate positive-pressure SPF chicken isolator for 22 days. Group A was the control group, and the chickens in group B were inoculated with $0.1 \mathrm{ml}$ of $10^{4.5} \mathrm{EID}_{50}$ of the isolate IBV/chicken/Iran/UTIVO-C/2014 (KR869776) via the oculonasal route at the age of 14 days [14]. Group A (control) received $0.1 \mathrm{ml}$ of PBS via the same route. Kidney tissue samples were then collected on days 2 and 7 postinoculation (dpi).

\section{Histopathological examination}

Histopathological examination of the collected kidney tissue samples of both groups, after fixation in phosphatebuffered $10 \%$ formalin, was done using hematoxylin \& eosin (HE) staining.

\section{RNA extraction}

RNA was extracted from collected tissue samples using a High Pure RNA Tissue Kit (Roche, Germany, catalog no. 12033674001) according to the manufacturer's protocol.

\section{Real-time RT-PCR}

Real-time PCR was used to amplify a conserved sequence of the IBV genome within the 5'-untranslated region (UTR). The antisense primer IBV5'GU391 (5'-GCT TTT GAG CCT AGC GTT-3') and the sense primer IBV5'GL533 (5'-GCC ATG TTG TCA CTG TCT ATT G-3') with the corresponding TaqMan dual-labeled probe FAM IBV5' G BHQ1 (5'-CAC CAC CAG AAC CTG TCA CCT C-3') were used. The real-time PCR reaction mix contained $3.25 \mu \mathrm{l}$ of nuclease-free water, $12.5 \mu \mathrm{l}$ of 2X RT-PCR master mix (QuantiTect Multiplex RT-PCR Kit, QIAGEN, Germany, catalog no. 204643), $0.25 \mu \mathrm{l}$ of enzyme mix (QuantiTect Multiplex RT-PCR Kit, QIAGEN, Germany), $5 \mu \mathrm{l}$ of template RNA, $0.75 \mu \mathrm{l}$ of each primer at a final concentration of $10 \mu \mathrm{M}$, and $2.5 \mu \mathrm{l}$ of probe at a final concentration of $0.1 \mu \mathrm{M}$. The PCR cycling parameters were as follows: $50{ }^{\circ} \mathrm{C}$ for $20 \mathrm{~min}$ and $95{ }^{\circ} \mathrm{C}$ for $15 \mathrm{~min}$, followed by 40 cycles of $94{ }^{\circ} \mathrm{C}$ for $45 \mathrm{~s}$ and $60{ }^{\circ} \mathrm{C}$ for $45 \mathrm{~s}$.

\section{Protein extraction and 2DE analysis}

Protein was extracted from kidney tissue using a ReadyPrep Protein Extraction Kit (Bio-Rad, 1632086), and for the estimation of the protein concentration, a 2-D Quant Kit (GE Healthcare, 80-6483-56) was employed. Subsequently, extracts were loaded onto $7 \mathrm{~cm}$ IPG strips (Isoelectric Point (pI) 3-10) at first dimension and afterward, SDS-PAGE as the second dimension was carried out. To control bias and to reduce biological variation between samples, every three samples of a group were combined, and three repeats of 2-DE were performed under identical conditions. Universal detection of proteins on 2-DE gels was performed by staining the gels with the anionic dye Coomassie blue R-350 to visualize protein spots after 2-DE separation. Images were analyzed using Progenesis Same-Spots software. Protein 
spots that showed more than a twofold change were selected and were sent for mass spectrometry analysis.

\section{Protein spot identification by MS}

Proteins in excised gel pieces were sequenced by MALDITOF/TOF mass spectrometry. MS data were analyzed by comparison against the Uniprot database, using Mascot. Before the search was started, boundaries were set out as follows: trypsin as digesting enzyme with maximum missed cleavage of 1 position, carbamidomethyl (c) as a fixed modification, deamidation (NQ) and oxidation (M) as variable modifications, peptide mass tolerance set at $\pm 100 \mathrm{ppm}$, fragment mass tolerance set at $\pm 0.5 \mathrm{Da}$. The search was done for all taxonomy by MudPIT, scoring with the significance level set at a 95\% confidence interval $(p<0.05)$. Protein hits for "Gallus" were selected. If there were no hits for a "Gallus" species, even after the NCBI BLAST search, the highest score for the other species was selected instead.

\section{Protein-protein interaction network and bioinformatics}

The related protein-protein interaction (PPI) networks of candidate proteins listed in Table 1 were derived from the latest version of the String database (https://string-db.org, $\mathrm{V}$ : 10.5). Cytoscape (version 3.5.1) was used to construct PPI networks of identified proteins separately at 2 and 7 dpi, and their interactions were identified with up to 100 neighbors with high confidence $(0.7)$ to construct these networks [17]. To identify the function and class of each protein, Gene Ontology Consortium (https://geneontolo gy.org), Agbase (https://www.agbase.msstate.edu), and the Cytoscape application BiNGO (https://www.psb.ugent.be/ $\mathrm{cbd} /$ papers/BiNGO/Home.html), were used with Uniprot ID to obtain annotations $[18,19]$.

\section{Gene expression qPCR}

A two-step gene expression quantification experiment was done to measure the expression of selected genes. Total RNA extracted from the samples was used with a random hexamer primer to synthesize cDNA. The first step was to maximize primer-RNA template binding by incubation of $1 \mu \mathrm{l}$ of random hexamer with a $10-\mu \mathrm{l}$ sample of total RNA at $60{ }^{\circ} \mathrm{C}$ for $10 \mathrm{~min}$. Then, a reaction mixture containing $3 \mu \mathrm{l}$ of nuclease-free water, $4 \mu \mathrm{l}$ of 10X RT-PCR buffer, $1 \mu \mathrm{l}$ of dNTP, and $1 \mu \mathrm{l}$ reverse transcriptase (Roche catalog no. 11062603001) was added to the first mixture and incubated at $48{ }^{\circ} \mathrm{C}$ for $60 \mathrm{~min}$, and then $95{ }^{\circ} \mathrm{C}$ for $10 \mathrm{~min}$. Next, a real-time PCR reaction was done in a volume of $25 \mu \mathrm{l}$. The reaction mixture contained $5 \mu \mathrm{l}$ of cDNA, $12.5 \mu \mathrm{l}$ of Real-Q Plus 2x Master Mix Green (Ampliqon, Denmark, catalog no. A315402), $1 \mu \mathrm{l}$ of each primer $(10 \mu \mathrm{M})$, and $5.5 \mu \mathrm{l}$ of nuclease-free water.

A Rotor-Gene Q Cycler (QIAGEN, Hilden, Germany) was used to perform a three-step cycling program with melt curve analysis, as follows: $95^{\circ} \mathrm{C}$ for $10 \mathrm{~min}$, then 40 cycles of $94{ }^{\circ} \mathrm{C}$ for $15 \mathrm{~s}, 52{ }^{\circ} \mathrm{C}$ for $30 \mathrm{~s}$, and $72{ }^{\circ} \mathrm{C}$ for $30 \mathrm{~s}$, followed by a green color reaction. Finally, a melt curve was made as follows: ramp from $55^{\circ} \mathrm{C}$ to $95^{\circ} \mathrm{C}$ increments $1{ }^{\circ} \mathrm{C}$ rise and a 5-s wait at each step [20]. 28S ribosomal RNA was used as a reference gene (Forward primer: 28S F, 5'-GGCGAA GCCAGAGGAAACT-3. Reverse primer: 28S R, 5'-GAC GACCGATTTGCACGTC-3'. Probe: FAM-AGGACCGCT ACGGACCTCCACCATAMRA) [14].

\section{Results}

\section{Histopathological examination}

To confirm microscopic histopathological lesions and changes due to virus infection, H\&E-stained kidney tissue of both groups was examined. Pathological findings at 2 dpi showed nonspecific changes such as mild hyperemia, while at $7 \mathrm{dpi}$, multifocal infiltration of heterophils predominantly along with hyperemia in the interstitial tissue, was seen (Fig. 1).

\section{Confirmation of infection and viral load}

RT-qPCR was used to confirm viral infection in the challenged group and the lack of infection in the control group up to the end of the experiment. The RNA was subjected to RT-PCR using the IBV 5'-UTR primers and 28S rRNA as an internal control [14]. The results showed viral infection of the kidney of all chickens in the infected group at 2 and 7 dpi, while the control group remained negative (Figs. 2 and 3 ).

\section{DE}

Changes in protein expression levels were detected by analysis of 2DE gel images using Progenesis Same-Spots software. Statistical analysis was carried out using all qualitycontrol parameters. The analysis showed that 294 and 326 normalized spots were detected in the 2DE gel at 2 and 7 dpi, respectively, and protein spots with a $P$-value less than 0.05 and a fold change greater than 2 were considered significantly changed (Figs. 4 and 5). Five proteins in the 2 dpi samples and 22 proteins in the 7 dpi samples exhibited the most significant change in quantity in the $2 \mathrm{DE}$ analysis in comparison with their corresponding spots of the control groups. 
Table 1 Identities of protein spots with differential expression observed by 2DE analysis and sequencing by MS-MALDI/TOF/TOF

\begin{tabular}{|c|c|c|c|c|c|c|c|c|c|}
\hline UniProt ID & Name & Accession no & $\begin{array}{l}\text { Protein } \\
\text { score }\end{array}$ & $\begin{array}{l}\text { Nominal } \\
\text { Mass }\end{array}$ & $\begin{array}{l}\text { Calculated } \\
\text { pI }\end{array}$ & $\begin{array}{l}\text { Peptide } \\
\text { count }\end{array}$ & $\begin{array}{l}\text { Coverage } \\
(\%)\end{array}$ & $\mathrm{dpi}^{1}$ & $\begin{array}{l}\text { Fold } \\
\text { change }\end{array}$ \\
\hline P01994 & $\begin{array}{l}\text { Hemoglobin } \\
\text { subunit } \\
\text { alpha-A }\end{array}$ & gil52138655|NP_001004376.1 & 96 & 15533 & 8.54 & 142 & 10 & 2 & -5 \\
\hline P19352 & $\begin{array}{c}\text { Tropomyosin } \\
\text { beta chain }\end{array}$ & gi|971437473|XP_015132749.1 & 439 & 32871 & 4.69 & 284 & 20 & 2 & +2.1 \\
\hline Q9PU45 & Radixin & gil45382077|NP_990082.1 & 63 & 68555 & 6.1 & 577 & 1 & 2 & -4.4 \\
\hline P09102 & $\begin{array}{l}\text { Protein } \\
\text { disulfide- } \\
\text { isomerase }\end{array}$ & gil30923135|P09102.3 & 245 & 57773 & 4.69 & 515 & 8 & 2 & -4.4 \\
\hline Q5ZKA5 & $\begin{array}{l}\text { Bifunctional } \\
\text { methylene- } \\
\text { tetrahy- } \\
\text { drofolate } \\
\text { dehydroge- } \\
\text { nase/cyclo- } \\
\text { hydrolase, } \\
\text { mitochon- } \\
\text { drial }\end{array}$ & gil71897117|NP_001026531.1 & 47 & 31392 & 5.75 & 298 & 2 & 2 & +2.1 \\
\hline P08250 & $\begin{array}{l}\text { Apolipopro- } \\
\text { tein A-I }\end{array}$ & gil45382961INP_990856.1 & 329 & 30661 & 5.58 & 264 & 17 & 7 & +8.4 \\
\hline P0CB50 & $\begin{array}{l}\text { Peroxire- } \\
\text { doxin-1 }\end{array}$ & gil429836849|NP_001258861.1 & 306 & 22529 & 8.24 & 199 & 21 & 7 & -4.1 \\
\hline P24367 & $\begin{array}{l}\text { Peptidyl-pro- } \\
\text { lyl cis-trans } \\
\text { isomerase B }\end{array}$ & gil45382027INP_990792.1 & 208 & 22456 & 9.4 & 207 & 14 & 7 & -3.2 \\
\hline P01994 & $\begin{array}{l}\text { Hemoglobin } \\
\text { subunit } \\
\text { alpha-A }\end{array}$ & gil52138655|NP_001004376.1 & 108 & 15533 & 8.54 & 142 & 10 & 7 & -5 \\
\hline P19121 & $\begin{array}{l}\text { Serum albu- } \\
\text { min }\end{array}$ & gil766944282INP_990592.2 & 259 & 71868 & 5.51 & 615 & 6 & 7 & +7.6 \\
\hline Q9I923 & Regucalcin & gil45382019|NP_990060.1 & 667 & 33665 & 5.77 & 299 & 30 & 7 & +7.5 \\
\hline P07630 & $\begin{array}{l}\text { Carbonic } \\
\quad \text { anhydrase } 2\end{array}$ & gil46048696INP_990648.1 & 121 & 29388 & 6.56 & 260 & 10 & 7 & -4.1 \\
\hline Q5ZK84 & $\begin{array}{l}\text { Alcohol dehy- } \\
\text { drogenase } \\
{[\operatorname{NADP}(+)]}\end{array}$ & gil57529654INP_001006539.1 & 131 & 37338 & 7.66 & 327 & 7 & 7 & -2.1 \\
\hline Q5ZL72 & $\begin{array}{c}60 \mathrm{kDa} \text { heat } \\
\text { shock pro- } \\
\text { tein, mito- } \\
\text { chondrial }\end{array}$ & gil61098372|NP_001012934.1 & 382 & 61105 & 5.72 & 573 & 8 & 7 & -2.4 \\
\hline Q99JY0 & $\begin{array}{l}\text { 3-ketoacyl- } \\
\text { CoA } \\
\text { thiolase, } \\
\text { peroxisomal }\end{array}$ & NP_001184217.1 & 60 & 51639 & 9.43 & 475 & 1 & 7 & +3.4 \\
\hline P11501 & $\begin{array}{l}\text { Heat shock } \\
\text { protein HSP } \\
\text { 90-alpha }\end{array}$ & gil157954047INP_001103255.1 & 524 & 84406 & 5.01 & 728 & 11 & 7 & -4.4 \\
\hline P08110 & $\begin{array}{l}\text { Endoplasmin } \\
\text { precursor }\end{array}$ & gil45383562|NP_989620.1 & 381 & 91726 & 4.83 & 795 & 7 & 7 & -5.4 \\
\hline O42388 & $\begin{array}{l}\text { Ubiquitin-60S } \\
\text { ribosomal } \\
\text { protein L40 }\end{array}$ & gil47604954INP_990406.1 & 258 & 14740 & 9.87 & 128 & 26 & 7 & -4.3 \\
\hline Q5ZLB3 & $\begin{array}{l}\text { Heterogene- } \\
\text { ous nuclear } \\
\text { ribonucleo- } \\
\text { protein A1 }\end{array}$ & gi|971825931|NP_001305347.1 & 297 & 38167 & 9.39 & 320 & 15 & 7 & -4.4 \\
\hline
\end{tabular}


Table 1 (continued)

\begin{tabular}{|c|c|c|c|c|c|c|c|c|c|}
\hline UniProt ID & Name & Accession no & $\begin{array}{l}\text { Protein } \\
\text { score }\end{array}$ & $\begin{array}{l}\text { Nominal } \\
\text { Mass }\end{array}$ & $\begin{array}{l}\text { Calculated } \\
\text { pI }\end{array}$ & $\begin{array}{l}\text { Peptide } \\
\text { count }\end{array}$ & $\begin{array}{l}\text { Coverage } \\
(\%)\end{array}$ & $d p i^{1}$ & $\begin{array}{l}\text { Fold } \\
\text { change }\end{array}$ \\
\hline A0A1D5P198 & $\begin{array}{l}\text { Tubulin alpha- } \\
\text { 1B chain }\end{array}$ & gi|971437052|XP_015155803.1 & 238 & 50152 & 4.94 & 451 & 9 & 7 & +4.4 \\
\hline Q90835 & $\begin{array}{l}\text { Elonga- } \\
\text { tion factor } \\
1 \text {-alpha } 1\end{array}$ & gil1009287609|NP_001308445.1 & 112 & 50157 & 9.1 & 462 & 4 & 7 & -3.7 \\
\hline P02001 & $\begin{array}{l}\text { Hemoglobin } \\
\text { subunit } \\
\text { alpha-D }\end{array}$ & gil52138645INP_001004375.1 & 172 & 15742 & 7.01 & 141 & 21 & 7 & -4.3 \\
\hline Q5ZME1 & $\begin{array}{l}\text { Heterogene- } \\
\text { ous nuclear } \\
\text { ribonucleo- } \\
\text { proteins } \\
\text { A2/B }\end{array}$ & gil71896753|NP_001026156.1 & 325 & 3604 & 8.67 & 341 & 18 & 7 & -4.4 \\
\hline P31790 & $\begin{array}{l}\text { Retrovirus- } \\
\text { related Gag } \\
\text { polyprotein }\end{array}$ & gil399521|P31790.1 & 46 & 28877 & 8.45 & 255 & 3 & 7 & -3.7 \\
\hline Q5ZLC5 & $\begin{array}{l}\text { ATP synthase } \\
\text { subunit beta, } \\
\text { mitochon- } \\
\text { drial }\end{array}$ & gil448261627INP_001026562.2 & 104 & 56650 & 5.59 & 533 & 5 & 7 & +4.4 \\
\hline P09653 & $\begin{array}{l}\text { Tubulin beta- } 5 \\
\text { chain }\end{array}$ & gil71896411|NP_001026183.1 & 121 & 49979 & 4.77 & 446 & 4 & 7 & +4.4 \\
\hline Q8UVX3 & $\begin{array}{l}\text { ATP synthase } \\
\text { subunit } \\
\text { alpha, mito- } \\
\text { chondrial }\end{array}$ & gil45383566INP_989617.1 & 72 & 60186 & 9.29 & 507 & 2 & 7 & -2.5 \\
\hline
\end{tabular}

${ }^{1}$ PI: Days post infection

\section{Mass spectrometry and topological analysis of the PPI network}

Table 1 shows the identities of the protein spots with differential expression revealed by $2 \mathrm{DE}$ analysis and sequencing by MS-MALDI/TOF/TOF. It is apparent from this table that the proteins showing a fold change greater than 2 at $2 \mathrm{dpi}$ were mainly classified in the categories transfer/carrier protein, actin-binding motor protein, dehydrogenase hydrolase, RNA binding protein, aminoacyl-tRNA synthesis and Hsp90 family chaperone. The biological processes and molecular functions of these proteins are listed in Fig. 6 and 7. Some notable biological process findings are negative regulation of the apoptotic process, response to stress, response to endoplasmic reticulum stress, response to the virus, protein folding, cellular response to starvation, cell redox homeostasis, oxygen transport, and beta-actin filament organization (Fig. 6). In contrast, GO terms such as chaperone binding, Hsp90 protein binding, ATPase activity, hydrolase activity, RNA binding, oxidoreductase activity, methylenetetrahydrofolate dehydrogenase (NAD+) activity, lipid binding, oxygen transport, iron ion binding, and metal ion binding are prominent points of molecular function in Fig. 7. The corresponding PPI network at 2 dpi was constructed to investigate the molecular pathogenesis of the virus (Fig. 8). Topological graph analysis of this undirected PPI network reveals two connected components and six communities, consisting of 108 vertices and 628 edges. As shown in Table 2, the hub-bottleneck vertices of this network are Hsp90AB1, EPRS, HspD1, and GART, whereas the proposed non-hubbottleneck nodes consist of GAPDH, P4HB, ACLY, ALB, SRC, and SYK. Finally, the hub-non-bottleneck nodes are Hsp90B1, Hsp90AA1, SUGT1, MTHFD1, MTHFD2, and MTHFD1L [21, 22]. The highest stress scores of Hsp90AB1, GAPDH, EPRS, and HspD1 stand out in Table 1. Surprisingly, three hub-bottleneck vertices are also ranked in the top 10 highest closeness scores (Hsp90AB1, EPRS, and HspD1; Table 2). Further analysis of the network showed the two largest cliques with ten members, as follows:

Clique 1: GMPS, MTHFD1, ACLY, MTHFD1L, MTHFD2, MTHFD2L, ATIC, LOC427977, ACACB, and GART.

Clique 2: MTHFD1, ACLY, MTHFD1L, MTHFD2, MTHFD2L, SHMT1, GLDC, DMGDH, GART, and ALDH1L2.

The identification spots at 7 dpi resulted in 22 proteins, which are shown in Table 1. Most of the highlighted biological processes at $7 \mathrm{dpi}$ are the regulation of catalytic activity, 

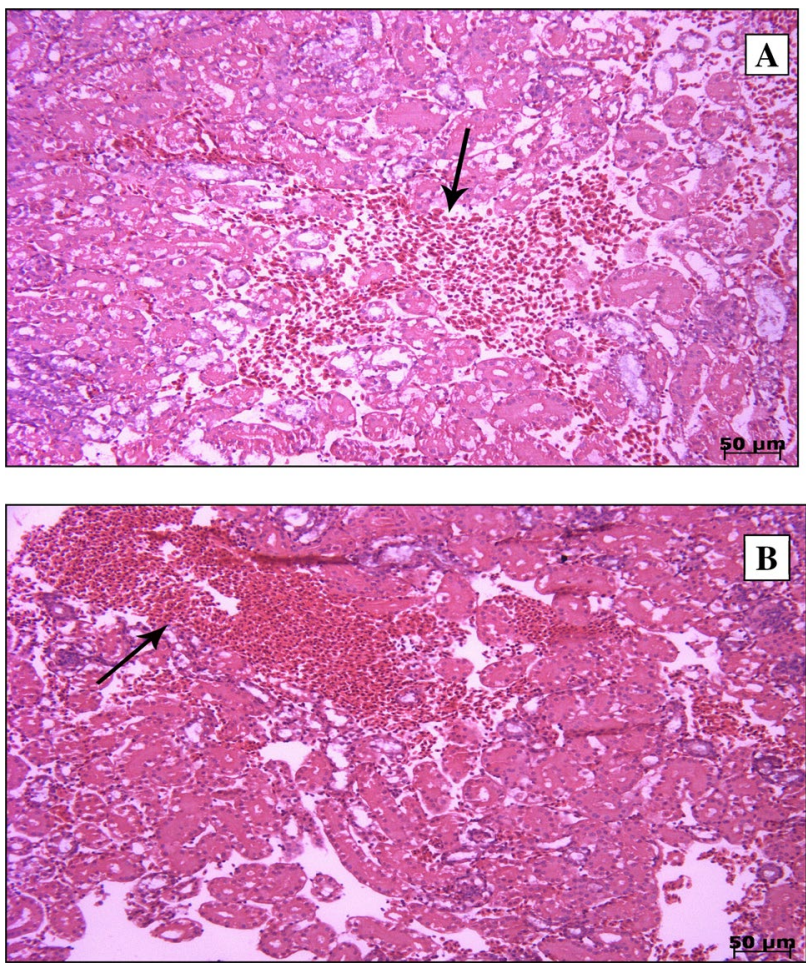

Fig. 1 Haematoxylin and eosin (H\&E) staining of 2 dpi (A) and 7 dpi (B) samples. Microscopic changes were observed in kidney tissue samples of the IS/1494/06-infected group of SPF chickens, including (A) mild hyperemia and (B) multifocal infiltration of heterophils along with hyperemia in the interstitial tissue

oxidation-reduction process, transport, viral process, negative regulation of the apoptotic process, protein folding, mRNA splicing via spliceosome, response to the virus, and innate immune response (Supplementary material 1). In addition, supplementary material 2 illustrates the molecular function of these proteins. The related PPI network at 7 dpi is as presented in Figure 9. The resulting PPI network consists of one connected component and five communities, which contain 116 vertices and 1099 edges. Topological analysis revealed that the hub-bottleneck vertices of the 7 dpi undirected PPI network are Hsp90AB1 and Hsp90B1, whereas the proposed non-hub-bottleneck nodes consist of ACLY, ACAC, DNAJC10, ACACB, LRRK1, LRRK2, and TUBB6, and finally, the hub-non bottleneck nodes are Hsp90AA1, HspA2, HspA8, TRAP1, HspA5, HspH1, and HspA4l (Table 3) [21, 22]. The highest stress score was obtained for ACAC, and the highest closeness score was obtained with Hsp90AB1 and DNAJC10 (Table 3). Additionally, subnetworks analysis identified the two largest cliques, with 14 members, as follows:

Clique 1: EHHADH, HSD17B 4, ENSGALG00000018744, ACOX1, ACACB, ACAC, HADHA, HADHB, ECI1, ACLY, ENSGALG00000007571, ACADS, ACOX3, and ECI2.
Clique 2: EHHADH, HSD 17 B 4, ENSGALG00000018744, ACOX1, ACACB, ACAC, HADHA, HADHB, ECI1, ACLY, ACADS, HADH, ACOX3, and ECI2.

\section{Gene expression qPCR}

To investigate the relationship between the proposed PPI network and the mechanism of pathogenesis, eight strong candidates among the immune system genes were chosen based on their correlation to the proposed genes of this study [23-25]. The role of the selected genes in the innate immune response and apoptosis and their involvement during coronavirus infection was established in previous studies [26-36]. Bcl, IFN, IL-4, IL-6, MYD88, STAT-1, TLR3, and TNF were selected using these criteria. Statistically, a $t$-test indicated a significant decrease in IFN, MYD88, and Bcl at 2 dpi $(p<0.05)$ and a significant decrease in IFN TLR3 at 7 dpi $(p<0.05)$. IL-6 and TNF showed a significant increase at both time points $(p<0.05)$ (Fig. 10).

\section{Discussion}

Several studies of coronaviruses have been presented in many different fields of molecular biology and have delivered significant findings. However, these studies have not been linked to each other systematically. The aim of the current study was to analyze the PPI network of intracellular events during infection with avian coronavirus isolate IBV/chicken/Iran/UTIVO$\mathrm{C} / 2014$, particularly pathological and immunological aspects of the disease, using proteomic analysis of changes occurring in avian kidney tissue. To our knowledge, three prior studies have used comparative proteomics in vivo to assess protein expression during infection with other strains of IBV [10, 12, 13]. Proteins that were down- or upregulated were identified by $2 \mathrm{DE}$ analysis and MS/TOF-TOF mass spectrometry and used for PPI network analysis. It has been shown previously that cellular metabolism can be altered due to infection. Corroborating this, based on the acquired GO annotations of the biological processes in this study, it is clear that avian coronavirus infection affects the metabolism of the host cell. A virus's ability to reach the highest rate of replication depends on its ability to control host cell metabolism to maintain the necessary vital biological processes. Some previous studies have pointed to a crucial role of Hsp90s family proteins in the replication of many viruses [37-39]. Through the entry of uncoated positive-sense RNA into the cytosol of the host cell, which immediately functions as an mRNA, avian coronavirus begins translating genes required for its replication using the host cell machinery [40, 41]. Thus, 16 functional non-structural proteins belonging to the replicase-transcriptase complex (RTC), encoded by ORF1a and ORF1b, are synthesized. 


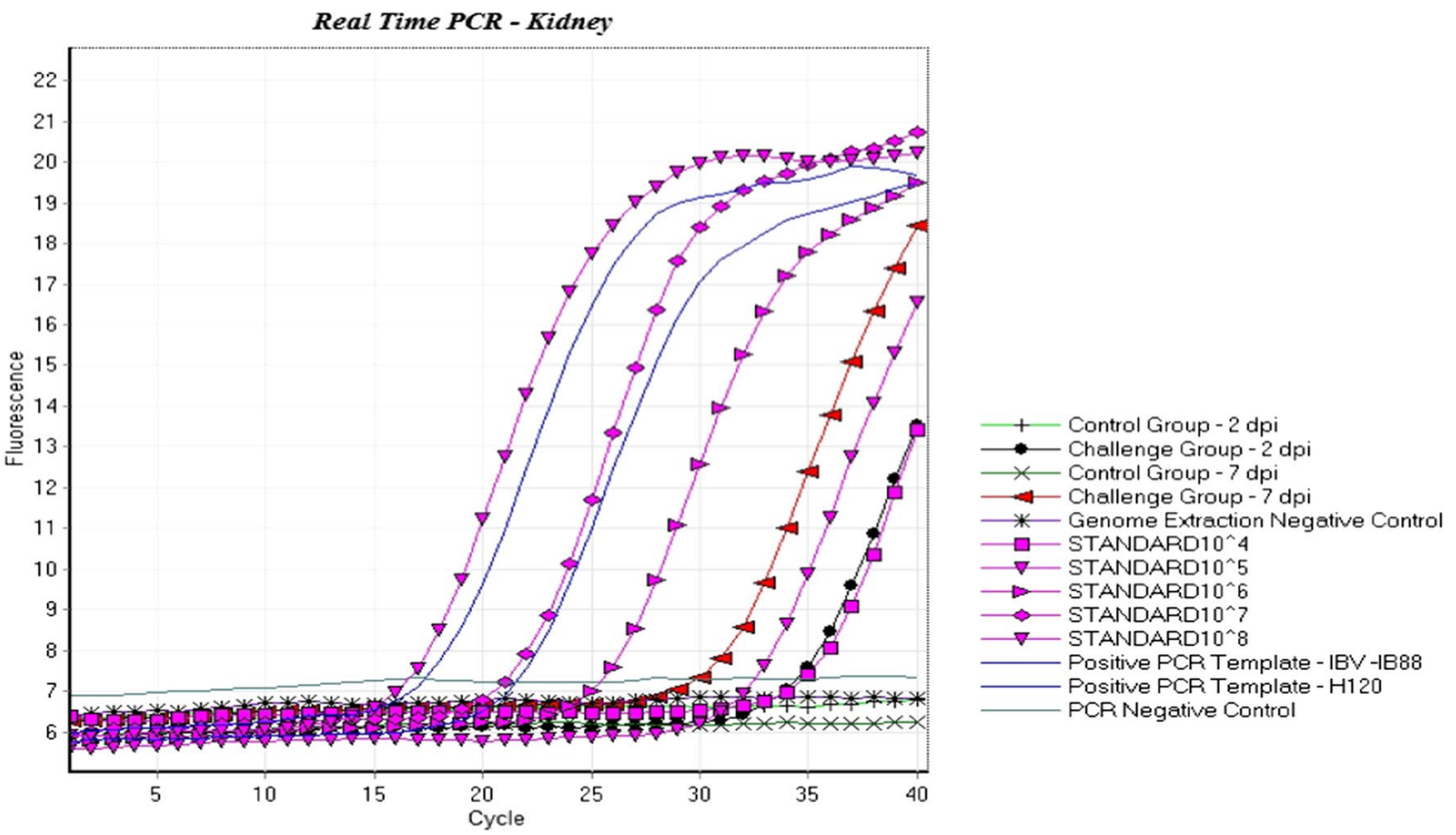

Fig. 2 Detection of IS/1494/06 in kidney tissue samples and determination of the viral load by real-time RT-PCR of a conserved sequence of the IBV genome. The control group remained uninfected up to the end of the experiment, and the infection of challenge group was confirmed by real-time RT-PCR.
, 2 dpi infected group; $\longrightarrow \lessdot, 7$ dpi control group; $\longleftarrow, 7$ dpi

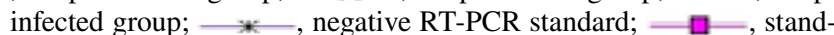
ard $10^{4} ; \square$, standard $10^{5} ; \Longrightarrow$, standard $10^{6} ; \Longrightarrow$, standard $10^{7} ; \multimap$, standard $10^{8} ; \square$, positive RT-PCR standard
Fig. 3 Standard curve of viral load determined by real-time RT-PCR. As expected, the viral load increased from 2 to $7 \mathrm{dpi}$, showing the normal progression of virus propagation

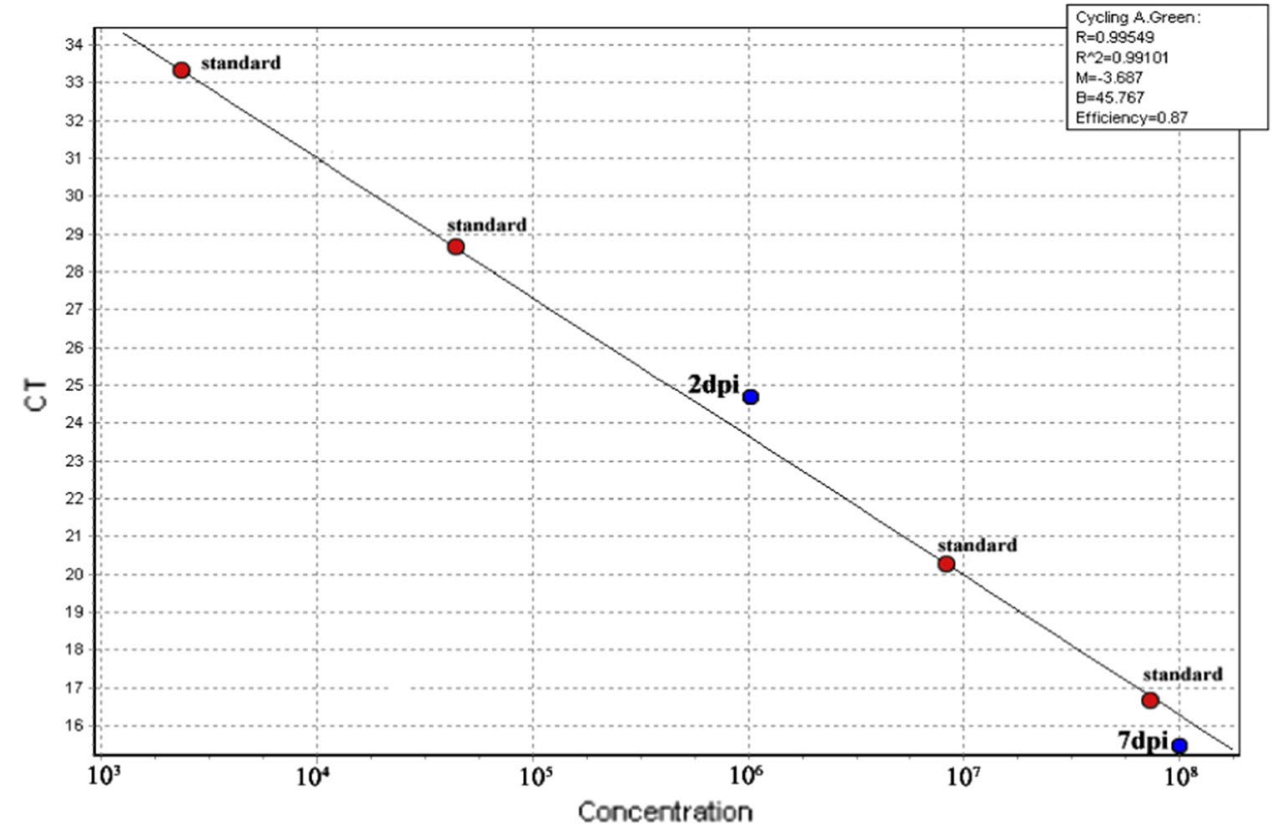

Subsequently, the plus-strand RNA is used as a template to synthesize the negative RNA strand in viral replication complexes (VRCs) [40, 42, 43]. A 50- to 100-fold increase in the amount of plus-strand RNA, a transcript from a negativestrand RNA, along with the translation of related viral proteins and other crucial proteins of the cell itself, all together produce a cluttered cytosol [40]. The accumulation of synthesized polypeptides causes ER stress, and the host cell must handle this overload. Hence, multifunctional heat shock proteins play a significant role in host cell survival. Hsp90AB1, a universal 
Fig. 4 Aligned 2DE images of extracted proteins from the control and infected groups at $2 \mathrm{dpi}$ using Progenesis Same-Spots software to detect differentially expressed proteins. Extracted proteins loaded on 7-cm IPG strips (pI 3-10) for the first dimension, and afterwards, SDS-PAGE was carried out as were stained using the anionic dye Coomassie blue R-350. Protein spots that showed a fold change $>2$ were selected the second dimension. Proteins

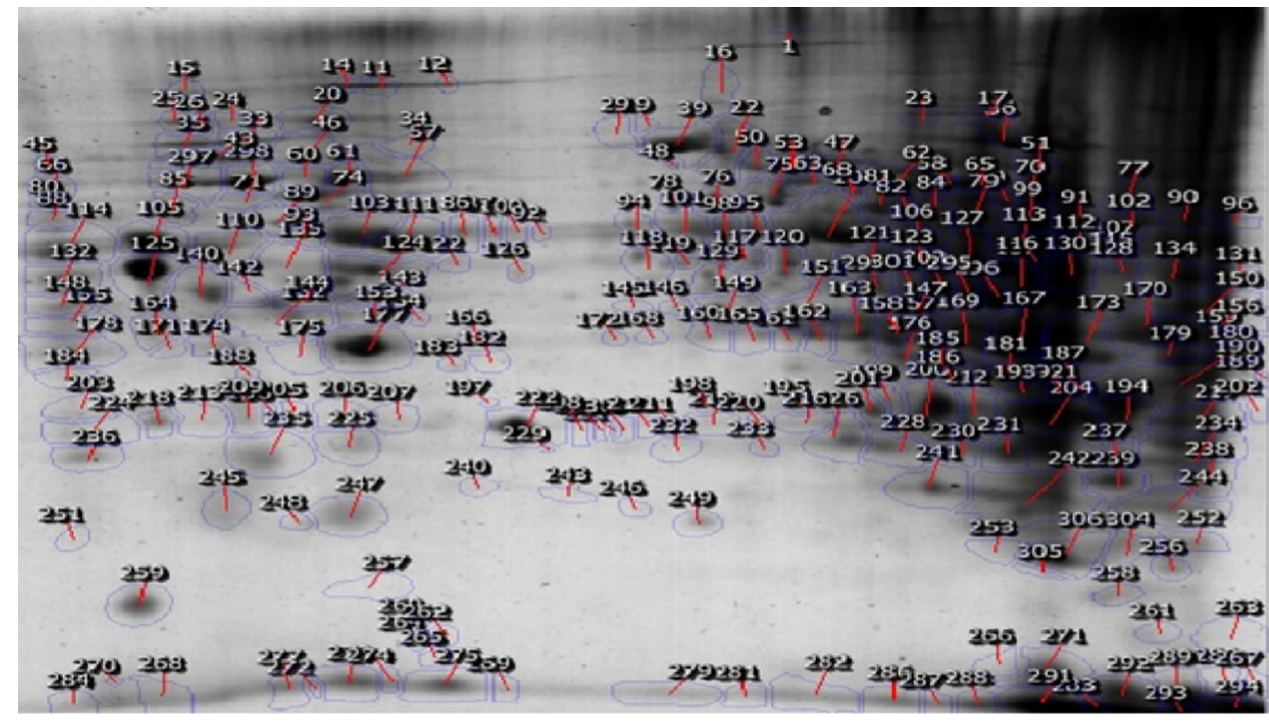

Fig. 5 Aligned 2DE images of extracted proteins from the control and infected groups at $7 \mathrm{dpi}$ using Progenesis Same-Spots software to detect differentially expressed proteins

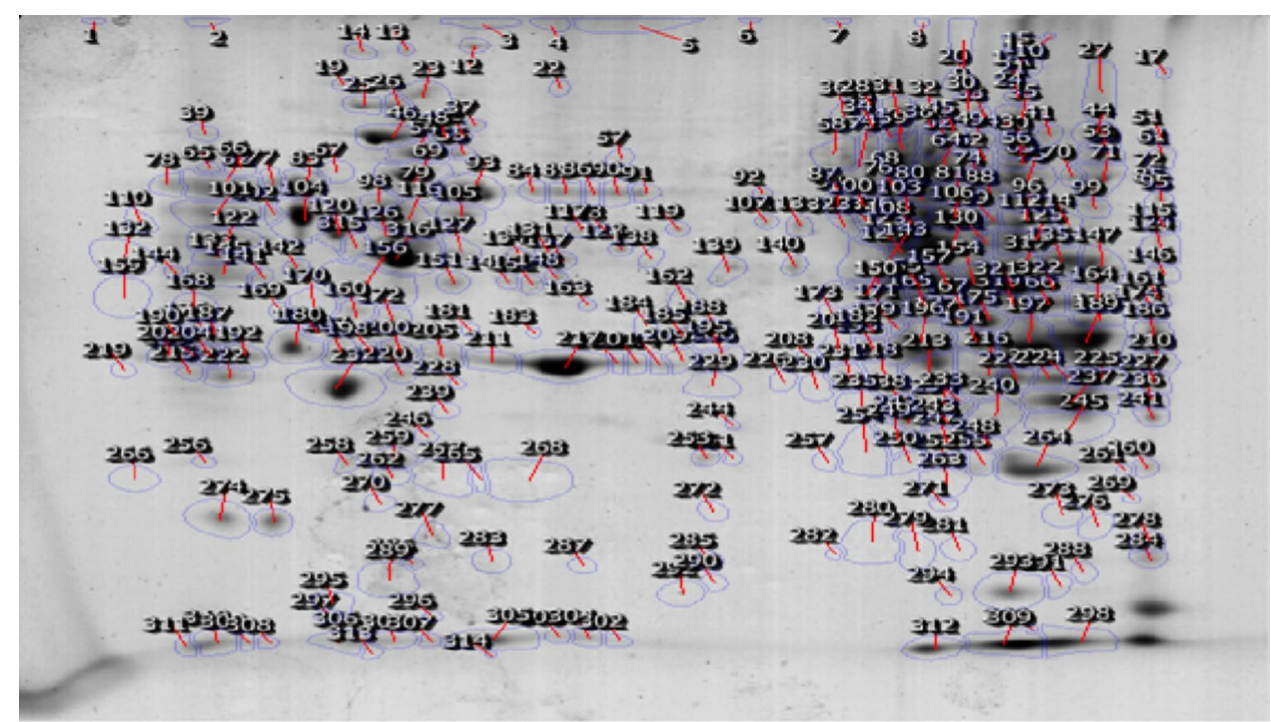

protein, has the greatest impact on the survival of both the host and the virus [44]. Also, abundant Hsp90 family proteins in the cytoplasm form functional complexes with various proteins that regulate different biological processes of the cell [44-46]. Moreover, other transcription factors such as IL-6, STAT1, NF- $\kappa$ B have a direct positive influence on Hsp90s expression levels [47]. Figure 10 that IL-6 is upregulated at $7 \mathrm{dpi}$, as determined by real-time qPCR $(p<0.05)$, in the infected group in comparison with the control group, which can upregulate the expression of Hsp90 family members [26, 31]. In such a situation, the prolyl-4-hydroxylase beta subunit $(\mathrm{P} 4 \mathrm{HB})$, which is a protein disulfide isomerase (PDI) may act as a molecular chaperone and facilitate proper folding of polypeptides and eliminate misfolded proteins [48, 49]. Furthermore, it has been shown that heat shock proteins (HSPs) are involved in the T-cell mediated immune response [25]. Besides that, the innate immune system is able to influence the adaptive immune system. Viral RNA is the foremost CoV-pathogenassociated molecular pattern (PAMP). Apparently, initiation of virus replication inside the host cell causes host-cell pathogen-recognition receptors (PRRs) such as Toll-like receptors (TLRs) and Retinoic acid-inducible gene I (RIG-I)-like receptors (RLRs) to induce expression of cytokines such as interferons (IFNs) [29, 50]. IFN production leads to the activation of IFN-stimulated genes (ISGs), which play an important early role in the antiviral defense apparatus of the innate immune system. This signal transduction activates STAT-1 as one of the most important tools against viral infection [50]. As shown in Figure 10, the decrease in IFN at 2 and 7 dpi was statistically significant $(p<0.05)$. This appears to allow the virus to conceal itself from the host immune system. This could be achieved by taking advantage of double-membrane vesicles (DMVs) and the actions of $3 b$ and $5 b$ accessory proteins, which play major roles as limiting agents of ISG expression 


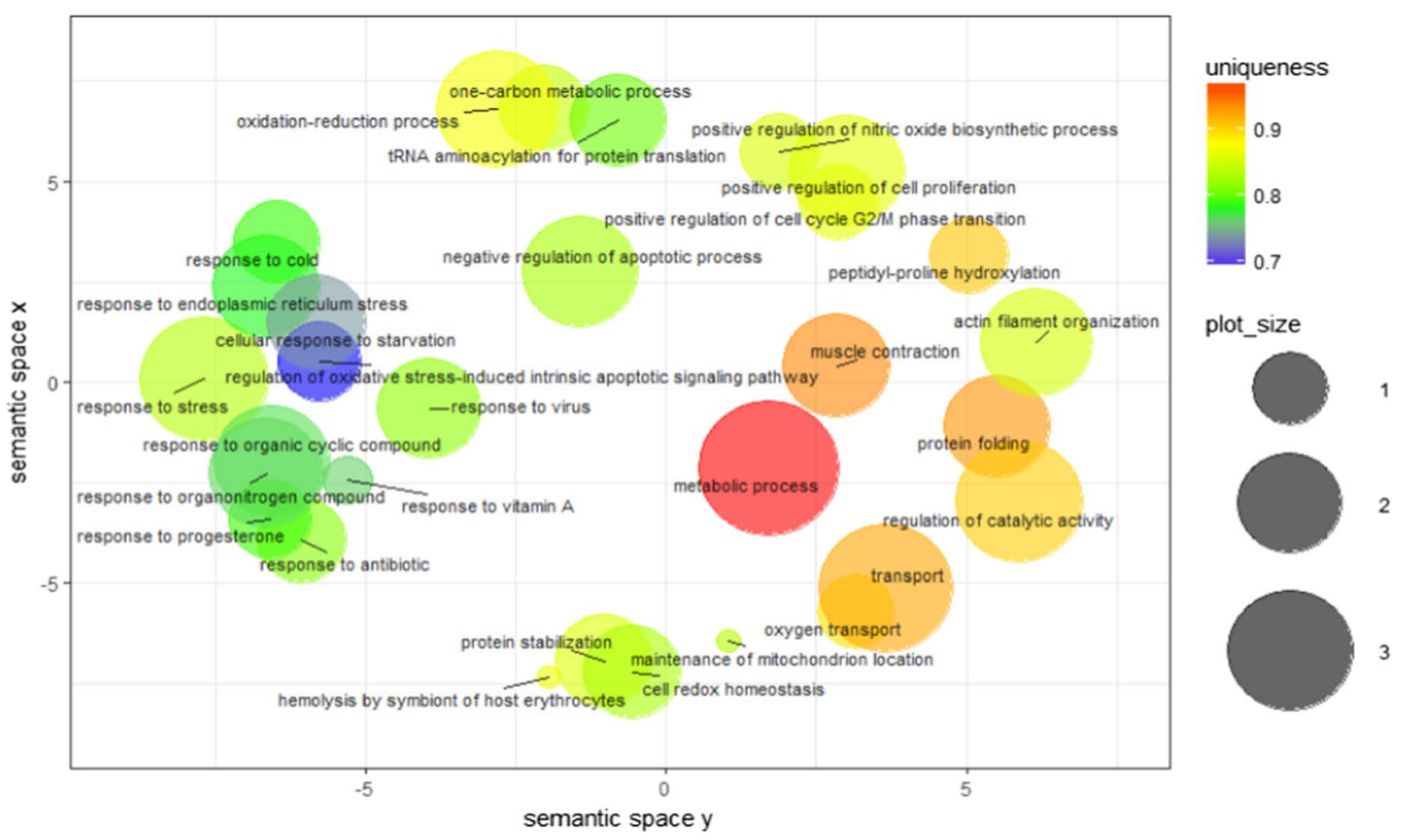

Fig. 6 Biological processes of 2 dpi samples. Semantic similaritybased scatter-plot of differentially expressed protein spots from kidney samples at 2 dpi. The allowed similarity was adjusted to 0.7 , and
simRel was selected as the similarity measure. Size indicates the frequency of the GO term in the underlying GOA database (bubbles of more general terms are larger)

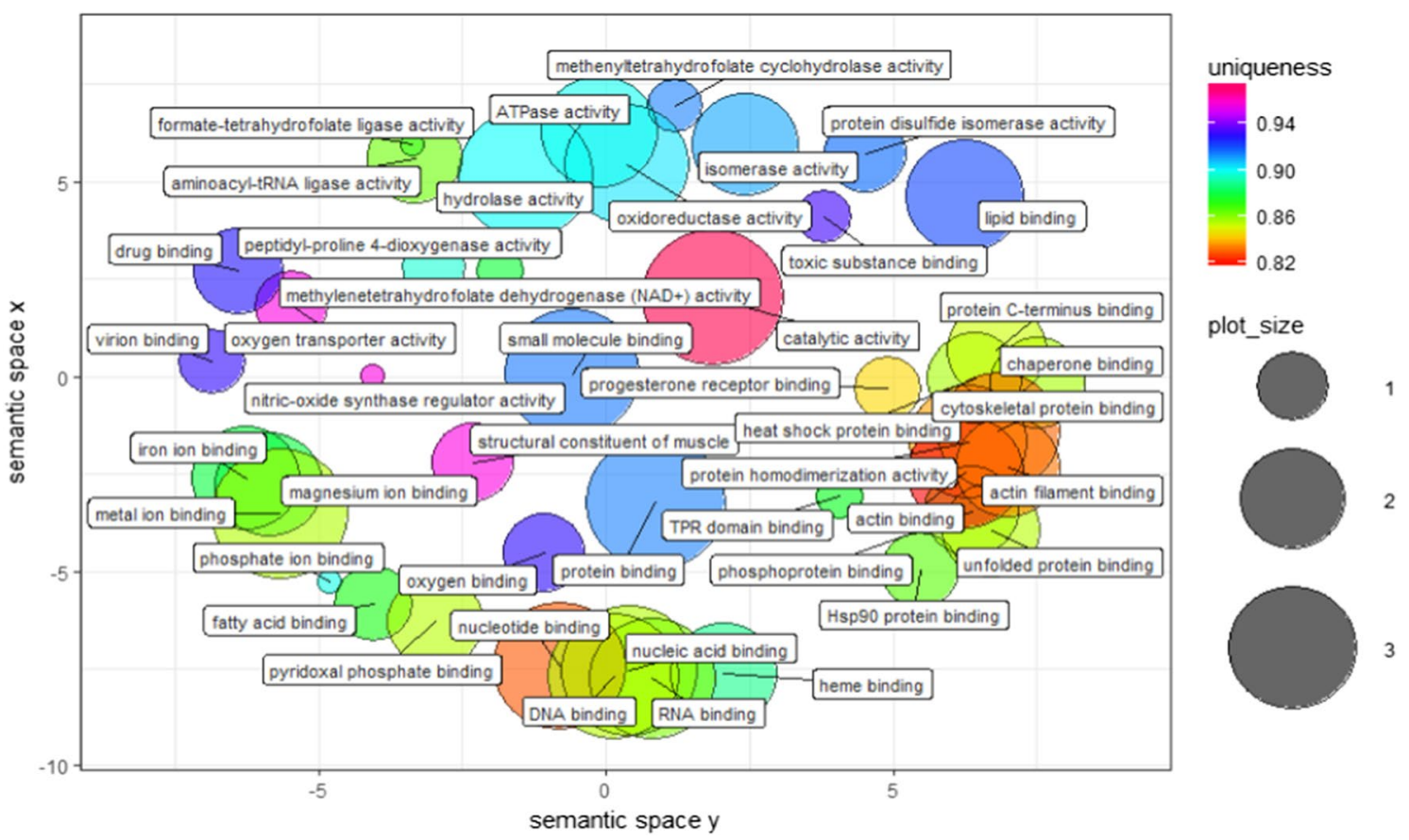

Fig. 7 Molecular functions of 2 dpi samples. Semantic similaritybased scatter-plot of differentially expressed protein spots from kidney samples at 2 dpi based on their functional annotations. The allowed similarity was adjusted to 0.7 , and simRel was selected as the similarity measure. Size indicates the frequency of the GO term in the underlying GOA database (bubbles of more general terms are larger) 
Fig. 8 Interaction network of differentially expressed proteins at 2 dpi (high confidence $<0.7$ ). The size of the circle shows the importance of the node in relation to its neighbors. Table 2 shows the centralities of important nodes. This is an undirected graph. Differences in the color of circles show that the proteins belong to different components of the graph

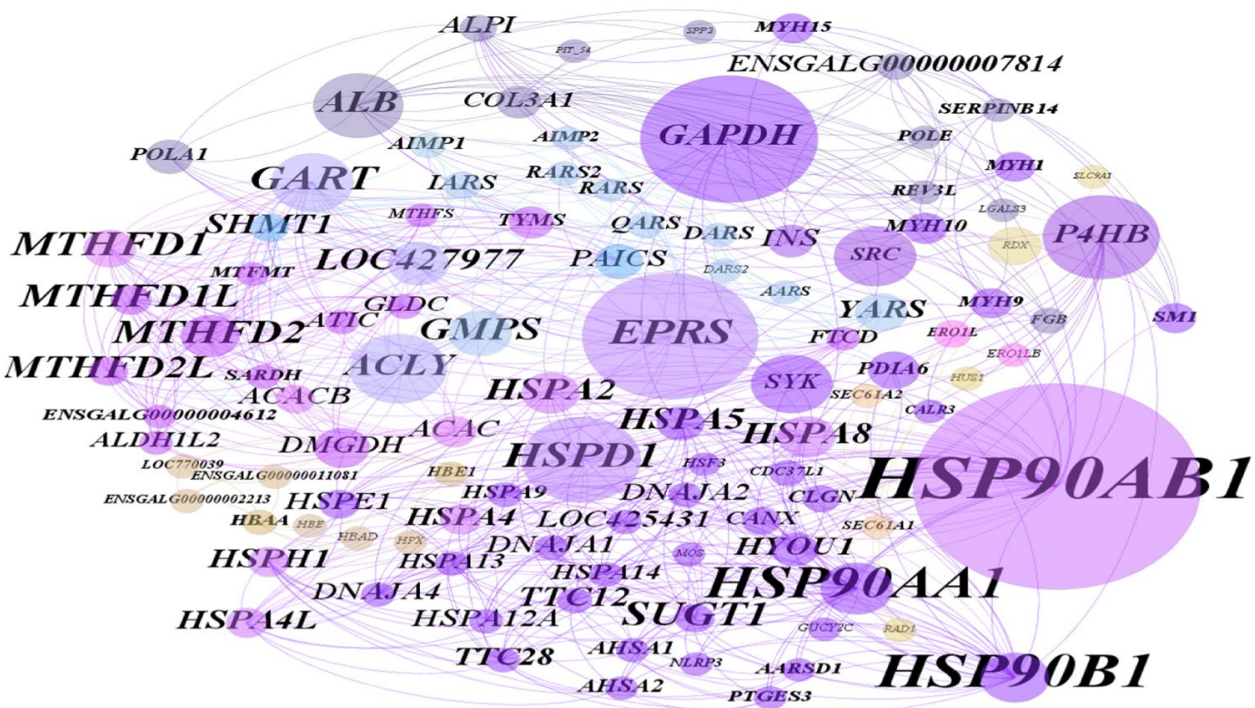

Table 2 Topological centrality analysis of the proposed PPI network for 2 dpi samples

\begin{tabular}{llllllll}
\hline Hubs & Hub degree & Betweenness & Bt. score & Stress & Stress score & Closeness & Closeness score \\
\hline HSP90AB1 & 45 & HSP90AB1 & 1250.8284158 & HSP90AB1 & 17008 & HSP90AB1 & 0.005988 \\
HSP90B1 & 35 & GAPDH & 710.3136824 & GAPDH & 13498 & HSPD1 & 0.0054054 \\
HSP90AA1 & 33 & EPRS & 701.9207744 & EPRS & 13448 & GAPDH & 0.0051546 \\
EPRS & 24 & HSPD1 & 422.3051613 & HSPD1 & 11240 & HSPA2 & 0.0051282 \\
HSPD1 & 24 & P4HB & 412.6733823 & GART & 5668 & HSPA8 & 0.0051282 \\
SUGT1 & 23 & ACLY & 313.7475918 & ACLY & 5508 & HSP90AA1 & 0.0050761 \\
GART & 23 & ALB & 282.1188723 & P4HB & 5244 & EPRS & 0.0050761 \\
MTHFD1 & 23 & SRC & 244.8398824 & SYK & 4892 & SYK & 0.0049261 \\
MTHFD2 & 22 & GART & 241.8886972 & ALB & 4834 & HSPA5 & 0.0048544 \\
MTHFD1L & 22 & SYK & 239.2131254 & GMPS & 4348 & HSP90B1 & 0.0048309 \\
\hline
\end{tabular}

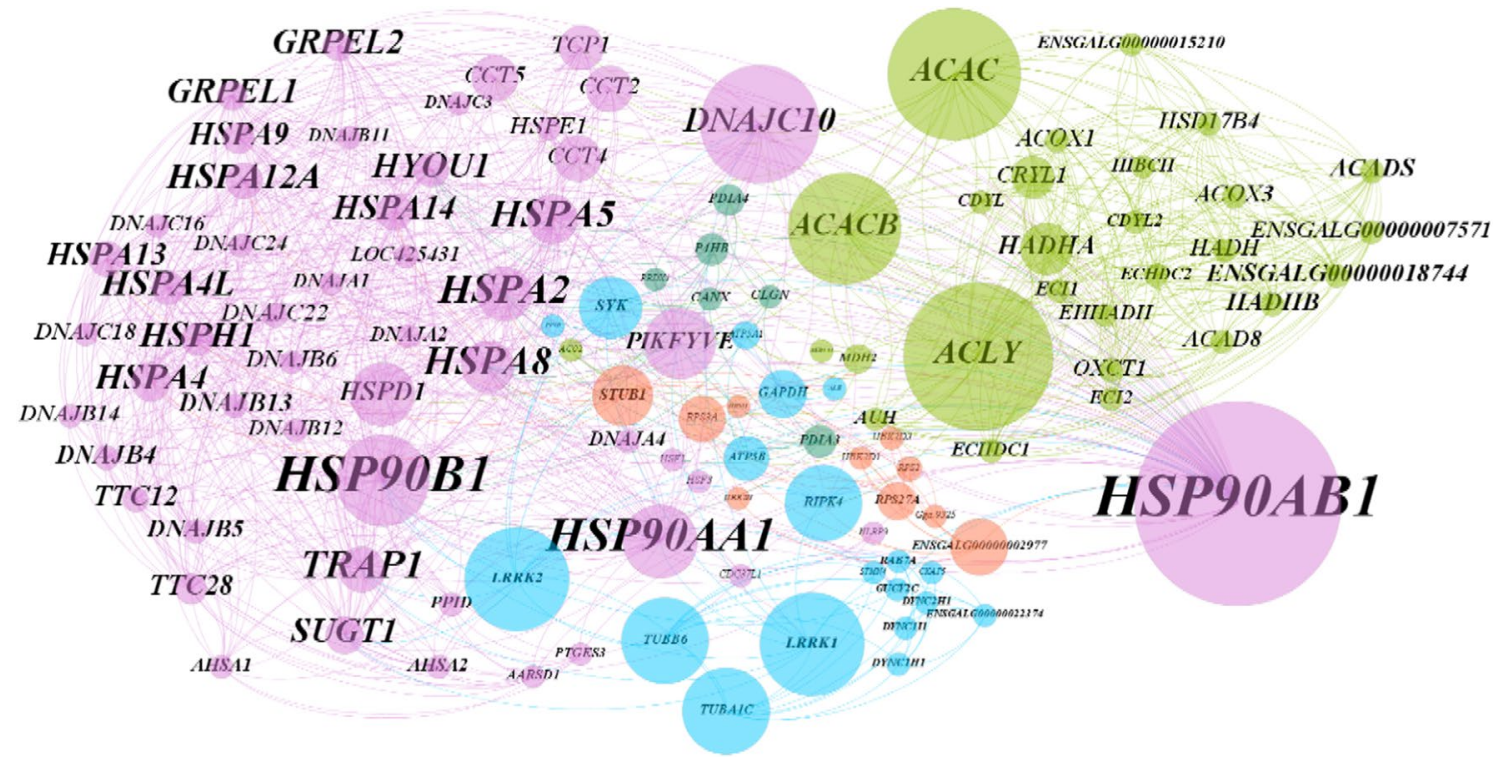

Fig. 9 Interaction network of differentially expressed proteins at $7 \mathrm{dpi}$ (high confidence $<0.7$ ). The size of the circle shows the importance of the node in relation to its neighbors. Table 3 shows the centralities of important nodes. This is an undirected graph. Differences in the color of circles show that the proteins belong to different components of the graph 
Table 3 Topological centrality analysis of the proposed PPI network for 7 dpi samples

\begin{tabular}{llllllll}
\hline Hub & Hub degree & Betweenness & Bt. score & Stress & Stress score & Closeness & Closeness score \\
\hline HSP90AB1 & 66 & HSP90AB1 & 1080.3207496 & ACAC & 92506 & HSP90AB1 & 0.0051546 \\
HSP90B1 & 57 & ACLY & 744.0224474 & ACACB & 85140 & DNAJC10 & 0.0047847 \\
HSP90AA1 & 51 & ACAC & 649.1397807 & ACLY & 43870 & HSP90B1 & 0.004717 \\
HSPA2 & 44 & DNAJC10 & 565.8880153 & DNAJC10 & 38896 & HSP90AA1 & 0.0046296 \\
HSPA & 43 & ACACB & 528.294562 & HSP90AB1 & 35712 & PIKFYVE & 0.0044843 \\
TRAP1 & 42 & LRRK1 & 480.0538792 & PIKFYVE & 35570 & TRAP1 & 0.004386 \\
HSPA5 & 42 & LRRK2 & 480.0538792 & HSPD1 & 33358 & HSPA2 & 0.004386 \\
HSPH1 & 37 & HSP90B1 & 408.5963847 & CCT2 & 28658 & HSPA8 & 0.0043668 \\
HSPA4L & 37 & TUBB6 & 378.9102564 & CCT4 & 28658 & HSPD1 & 0.0043668 \\
\hline
\end{tabular}

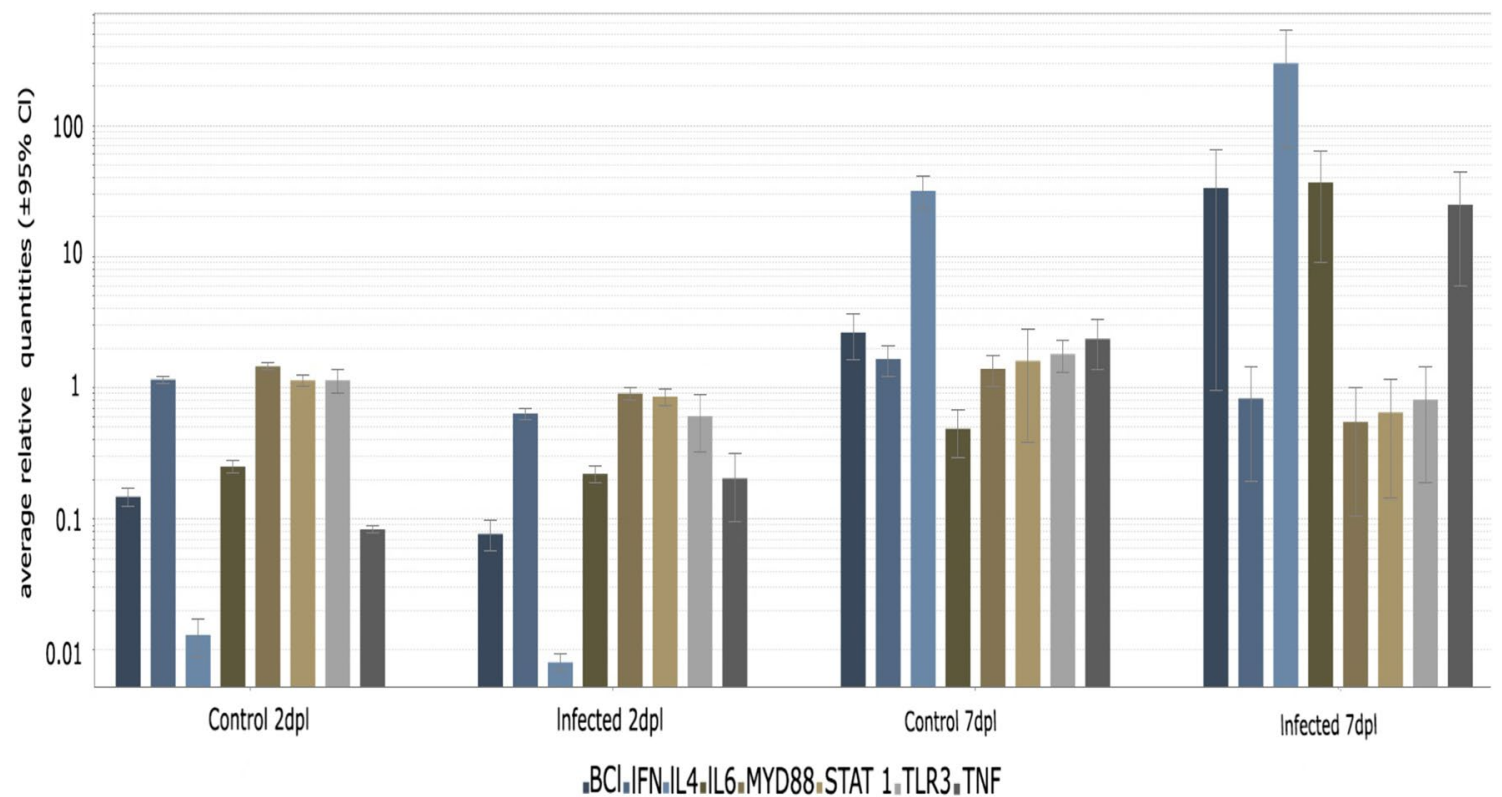

Fig. 10 Real-time qPCR analysis of eight selected genes in the IBV-inoculated and control groups. Fold change values were calculated using the $2^{-\Delta \Delta \mathrm{CT}}$ method with $28 \mathrm{~S}$ rRNA as a reference gene. Error bars represent the standard error of three independent repeats

[30, 51-53]. DMVs silence viral PAMPs, making them inaccessible to PRRs. In addition, the presence of a protein phosphatase 1 -binding domain in the $3 \mathrm{~b}$ accessory protein of avian $\mathrm{CoV}$ along with the ability of the $5 \mathrm{~b}$ accessory protein of the virus to reduce IFN mRNA expression results in a reduction of IFN expression during the early stage of infection [30, 51, 53]. This is in agreement with the overexpression of HSPs, which have a positive effect on the antiviral defense of the host cell. Another antiviral agent in the network that has a significant function is EPRS [23]. Amino-acyl tRNA-synthetases (ARSs) are crucial to the protein-synthesizing process. They create a linkage between amino acids and their corresponding tRNAglutamyl-prolyl tRNA synthetase (EPRS). EPRS is a member of ARS that acts in the context of mammalian cytoplasmic multi-tRNA synthetase complex (MCC). It is also expressed during stress situations such as viral infections, in which it functions together with GAPDH through the GAIT system $[23,54]$. Regarding the observed decrease in IFN during IBV infection, as mentioned above, the antiviral activity of EPRS might be decreased due to impairment of the GAIT system [23, 55-57]. Keeping subsequent major problems induced by the virus replication under control, such as increased cellular biochemical reactions, demands for energy sources, starvation, proteotoxic challenges, and hypoxia, all of which are due to increased biological processes involving acetyl-coenzyme A consumption, is another critical function that needs to be 
managed by the cell $[58,59]$. Autophagy mechanisms can help the cell to deal with the above-mentioned stressful situations. Avian coronavirus nsp6 has the ability to induce autophagy in the host cell itself [60]. Acetyl-coenzyme A, a key intermediate molecule that plays a pivotal role in intracellular biochemical reactions, must be regulated by increasing cell metabolism. ACLY increases the cytoplasmic levels of AcCoA by back-conversion of citrate to compensate for its shortages $[61,62]$. The anti-apoptotic cytoplasmic protein, Bcl-2, which negatively regulates autophagy, showed a statistically significant $(p<0.05)$ reduction based on the qPCR result (Fig. 10). This would result in the promotion of autophagy in infected cell [63-67].

The data from this study suggest that the process of pathogenesis that occurs during avian coronavirus infection involves the regulation of vital cellular processes and the gradual disruption of critical cellular functions. Host genes such as Hsp90AB1, EPRS, GAPDH, HspD1, ACLY, and $\mathrm{P} 4 \mathrm{HB}$, which have not been identified in previous studies, are potentially involved in the process of pathogenesis and should be investigated further.

\section{References}

1. Schalk AF, Hawn MC (1931) An apparently new respiratory disease of baby chicks. J Am Vet Med Assoc 78(19):413-422

2. Jackwood MW (2012) Review of infectious bronchitis virus around the world invited review-review of infectious bronchitis virus around the world. Avian Dis 56(4):634-641

3. de Wit JJS, Cook JKA, van der Heijden HMJF (2011) Infectious bronchitis virus variants: a review of the history, current situation and control measures. Avian Pathol 40(3):223-235. https ://doi.org/10.1080/03079457.2011.566260

4. Ramage HR et al (2015) A combined proteomics/genomics approach links hepatitis $\mathrm{C}$ virus infection with nonsense-mediated mRNA decay. Mol Cell 57(2):329-340

5. Matheson NJ et al (2015) Cell surface proteomic map of HIV infection reveals antagonism of amino acid metabolism by $\mathrm{Vpu}$ and Nef. Cell Host Microbe 18(4):409-423

6. Kroeker AL, Coombs KM (2014) Systems biology unravels interferon responses to respiratory virus infections. World J Biol Chem 5(1):12-25. https://doi.org/10.4331/wjbc.v5.i1.12

7. Mancone $\mathrm{C}$ et al (2013) Applying proteomic technology to clinical virology. Clin Microbiol Infect 19(1):23-28. https:// doi.org/10.1111/1469-0691.12029

8. Munday DC et al (2010) Quantitative proteomic analysis of A549 cells infected with human respiratory syncytial virus. Mol Cell Proteomics 9(11):2438-2459. https://doi.org/10.1074/mcp. M110.001859

9. Liu N et al (2008) Proteomics analysis of differential expression of cellular proteins in response to avian $\mathrm{H} 9 \mathrm{~N} 2$ virus infection in human cells. Proteomics 8(9):1851-1858

10. Cao Z et al (2012) Proteomics analysis of differentially expressed proteins in chicken trachea and kidney after infection with the highly virulent and attenuated coronavirus infectious bronchitis virus in vivo. Proteome Sci 10(1):24. https:// doi.org/10.1186/1477-5956-10-24

11. Emmott E, Smith C, Emmett SR, Dove BK, Hiscox JA (2010) Elucidation of the avian nucleolar proteome by quantitative proteomics using SILAC and changes in cells infected with the coronavirus infectious bronchitis virus. Proteomics 10(19):3558-3562. https://doi.org/10.1002/pmic.201000139

12. Emmott E, Rodgers MA, Macdonald A, McCrory S, Ajuh P, Hiscox JA (2010) "Quantitative proteomics using stable isotope labeling with amino acids in cell culture reveals changes in the cytoplasmic, nuclear, and nucleolar proteomes in Vero cells infected with the coronavirus infectious bronchitis virus. Mol Cell Proteomics 9(9):1920-1936. https://doi.org/10.1074/mcp. M900345-MCP200

13. Sun J, Han Z, Shao Y, Cao Z, Kong X, Liu S (2014) Comparative proteome analysis of tracheal tissues in response to infectious bronchitis coronavirus, Newcastle disease virus, and avian influenza virus H9 subtype virus infection. Proteomics 14(11):1403-1423. https://doi.org/10.1002/pmic.201300404

14. Najafi $\mathrm{H}$ et al (2016) Pathogenicity characteristics of an Iranian variant-2 (IS-1494) like infectious bronchitis virus in experimentally infected SPF chickens. Acta Virol. 60(4):393

15. Hosseini H, Fard MHB, Charkhkar S, Morshed R (2015) Epidemiology of avian infectious bronchitis virus genotypes in Iran (2010-2014). Avian Dis 59(3):431-435

16. Hamadan AM et al (2017) Genotyping of Avian infectious bronchitis viruses in Iran (2015-2017) reveals domination of IS-1494 like virus. Virus Res 240:101-106

17. Shannon P et al (2003) Cytoscape: a software environment for integrated models of biomolecular interaction networks. Genome Res 13(11):2498-2504. https://doi.org/10.1101/gr.1239303

18. G. O. Consortium (2015) Gene ontology consortium: going forward. Nucleic Acids Res 43(D1):D1049-D1056

19. Maere S, Heymans K, Kuiper M (2005) BiNGO: a Cytoscape plugin to assess overrepresentation of gene ontology categories in biological networks. Bioinformatics 21(16):3448-3449

20. Nolan T, Hands RE, Bustin SA (2006) Quantification of mRNA using real-time RT-PCR. Nat Protoc 1(3):1559-1582

21. Yu H, Kim PM, Sprecher E, Trifonov V, Gerstein M (2007) The importance of bottlenecks in protein networks: correlation with gene essentiality and expression dynamics. PLoS Comput Biol 3(4):e59

22. Dietz K, Jacquot J, Harris G (2010) Hubs and bottlenecks in plant molecular signalling networks. New Phytol 188(4):919-938

23. Lee E-Y et al (2016) Infection-specific phosphorylation of glutamyl-prolyl tRNA synthetase induces antiviral immunity. Nat Immunol 17:1252-1262

24. Pietrocola F, Galluzzi L, Pedro JMB-S, Madeo F, Kroemer G (2015) Acetyl coenzyme A: a central metabolite and second messenger. Cell Metab 21(6):805-821

25. Srivastava PK, Menoret A, Basu S, Binder RJ, McQuade KL (1998) Heat shock proteins come of age: primitive functions acquire new roles in an adaptive world. Immunity 8(6):657-665

26. Wang $\mathrm{W}$ et al (2007) Up-regulation of IL-6 and TNF- $\alpha$ induced by SARS-coronavirus spike protein in murine macrophages via NF-кB pathway. Virus Res 128(1):1-8

27. Clay CC et al (2014) Severe acute respiratory syndrome-coronavirus infection in aged nonhuman primates is associated with modulated pulmonary and systemic immune responses. Immun Ageing 11(1):4. https://doi.org/10.1186/1742-4933-11-4

28. Maier HJ, Britton P (2012) Involvement of autophagy in coronavirus replication. Viruses 4(12):3440-3451. https://doi.org/10.3390/ v4123440

29. Vidalain PO, Tangy F (2010) Virus-host protein interactions in RNA viruses. Microbes Infect 12(14-15):1134-1143. https://doi. org/10.1016/j.micinf.2010.09.001

30. Kint $\mathbf{J}$ et al (2016) Infectious bronchitis coronavirus limits interferon production by inducing a host shutoff that requires accessory protein 5b. J Virol 90(16):7519-7528 
31. Cong F, Liu X, Han Z, Shao Y, Kong X, Liu S (2013) Transcriptome analysis of chicken kidney tissues following coronavirus avian infectious bronchitis virus infection. BMC Genomics 14(1):743. https://doi.org/10.1186/1471-2164-14-743

32. Li FQ, Tam JP, Liu DX (2007) Cell cycle arrest and apoptosis induced by the coronavirus infectious bronchitis virus in the absence of p53. Virology 365(2):435-445. https://doi. org/10.1016/j.virol.2007.04.015

33. Fernando FS et al (2015) Increased expression of interleukin-6 related to nephritis in chickens challenged with an avian infectious bronchitis virus variant. Pesqui Veterinária Bras 35(3):216-222

34. Kameka AM, Haddadi S, Kim DS, Cork SC, Abdul-Careem MF (2014) Induction of innate immune response following infectious bronchitis corona virus infection in the respiratory tract of chickens. Virology 450:114-121

35. Chhabra R, Chantrey J, Ganapathy K (2015) Immune responses to virulent and vaccine strains of infectious bronchitis viruses in chickens. Viral Immunol 28(9):478-488

36. Yang $\mathrm{Y}$ et al (2005) Bcl-xL inhibits T-cell apoptosis induced by expression of SARS coronavirus E protein in the absence of growth factors. Biochem J 392(1):135-143

37. Das I et al (2014) Heat shock protein 90 positively regulates Chikungunya virus replication by stabilizing viral non-structural protein nsP2 during infection. PLoS ONE 9(6):e100531

38. Smith AP, Haystead TAJ (2017) Hsp90: a key target in HIV infection. Future Med 2017:55-59

39. Gao J et al (2014) Inhibition of HSP90 attenuates porcine reproductive and respiratory syndrome virus production in vitro. Virol J 11(1): 17

40. Sawicki SG, Sawicki DL, Siddell SG (2007) A contemporary view of coronavirus transcription. J Virol 81(1):20-29

41. Masters PS (2006) The molecular biology of coronaviruses. Adv Virus Res 65(06):193-292. https://doi.org/10.1016/S0065 $-3527(06) 66005-3$

42. Nagy PD, Pogany J (2012) The dependence of viral RNA replication on co-opted host factors. Nat Rev Microbiol 10(2):137-149

43. Fung TS, Liu DX (2014) Coronavirus infection, ER stress, apoptosis and innate immunity. Front Microbiol 5:296

44. Haase M, Fitze G (2016) HSP90AB1: helping the good and the bad. Gene 575(2):171-186

45. Taipale M, Jarosz DF, Lindquist S (2010) HSP90 at the hub of protein homeostasis: emerging mechanistic insights. Nat Rev Mol cell Biol 11(7):515-528

46. Nagy PD, Wang RY, Pogany J, Hafren A, Makinen K (2011) Emerging picture of host chaperone and cyclophilin roles in RNA virus replication. Virology 411(2):374-382

47. Prodromou C (2017) Regulatory mechanisms of Hsp90. Biochem Mol Biol J 3:1

48. Gorres KL, Raines RT (2010) Prolyl 4-hydroxylase. Crit Rev Biochem Mol Biol 45(2):106-124

49. Sun $\mathrm{S}$ et al (2017) Endoplasmic reticulum chaperone prolyl 4-hydroxylase, beta polypeptide (P4HB) promotes malignant phenotypes in glioma via MAPK signaling. Oncotarget 8(42):71911

50. Schoggins JW, Rice CM (2011) Interferon-stimulated genes and their antiviral effector functions. Curr Opin Virol 1(6):519-525
51. Kindler E, Thiel V (2014) To sense or not to sense viral RNAessentials of coronavirus innate immune evasion. Curr Opin Microbiol 20:69-75

52. Kint $\mathbf{J}$ et al (2015) Activation of the chicken type I interferon response by infectious bronchitis coronavirus. J Virol 89(2):1156-1167

53. Pendleton AR, Machamer CE (2006) Differential localization and turnover of infectious bronchitis virus $3 \mathrm{~b}$ protein in mammalian versus avian cells. Virology 345(2):337-345. https://doi. org/10.1016/j.virol.2005.09.069

54. Mukhopadhyay R, Jia J, Arif A, Ray PS, Fox PL (2009) The GAIT system: a gatekeeper of inflammatory gene expression. Trends Biochem Sci 34(7):324-331

55. Mazumder B, Li X, Barik S (2010) Translation control: a multifaceted regulator of inflammatory response. J Immunol 184(7):3311-3319

56. Sola I, Mateos-Gomez PA, Almazan F, Zuñiga S, Enjuanes L (2011) RNA-RNA and RNA-protein interactions in coronavirus replication and transcription. RNA Biol 8(2):237-248. https://doi. org/10.4161/rna.8.2.14991

57. Zhong Y, Tan YW, Liu DX (2012) Recent progress in studies of arterivirus-and coronavirus-host interactions. Viruses 4(6):980-1010

58. Santoro MG (2000) Heat shock factors and the control of the stress response. Biochem Pharmacol 59(1):55-63

59. Ron D, Walter P (2007) Signal integration in the endoplasmic reticulum unfolded protein response. Nat Rev Mol cell Biol 8(7):519-529

60. Cottam EM et al (2011) Coronavirus nsp6 proteins generate autophagosomes from the endoplasmic reticulum via an omegasome intermediate. Autophagy 7(11):1335-1347

61. Mariño G et al (2014) Regulation of autophagy by cytosolic acetyl-coenzyme A. Mol Cell 53(5):710-725

62. Maier HJ et al (2013) Visualizing the autophagy pathwayc in avian cells and its application to studying infectious bronchitis virus. Autophagy 9(4):496-509. https://doi.org/10.4161/auto.23465 (INSO-IAHINAM-InstituteforAnimalHealth(IAH))

63. McCullough KD, Martindale JL, Klotz L-O, Aw T-Y, Holbrook NJ (2001) Gadd153 sensitizes cells to endoplasmic reticulum stress by down-regulating $\mathrm{Bcl} 2$ and perturbing the cellular redox state. Mol Cell Biol 21(4):1249-1259

64. Sano R, Reed JC (2013) ER stress-induced cell death mechanisms. Biochim Biophys Acta (BBA)-Mol Cell Res 1833(12):3460-3470

65. Adams JM, Cory S (1998) The Bcl-2 protein family: arbiters of cell survival. Science (80) 281(5381):1322-1326

66. Liao Y, Fung TS, Huang M, Fang SG, Zhong Y, Liu DX (2013) Upregulation of CHOP/GADD153 during coronavirus infectious bronchitis virus infection modulates apoptosis by restricting activation of the extracellular signal-regulated kinase pathway. J Virol 87(14):8124-8134

67. Kroemer G, Mariño G, Levine B (2010) Autophagy and the integrated stress response. Mol Cell 40(2):280-293

Publisher's Note Springer Nature remains neutral with regard to jurisdictional claims in published maps and institutional affiliations. 